\title{
Ground motion characteristics and their cumulative impacts to burst risks in underground coal mines
}

\author{
Changbin Wang • Guangyao Si $\cdot$ Chengguo Zhang $(\mathbb{D} \cdot$ Anye Cao • \\ Ismet Canbulat
}

Received: 12 April 2021/Accepted: 2 January 2022/Published online: 4 February 2022

(C) The Author(s) 2022

\begin{abstract}
Ground motions resulting from seismic waves are one of the main factors to trigger coal burst hazards in underground mines. Ground motion induced dynamic impacts may apply to the highly stressed coal/rock mass and initiate dynamic failure. Although ground motion analysis has been widely used in burst-prone hard rock mines for designing support systems, there are only few studies focusing on the understanding ground motion characteristics in coal mines and their relationship with the coal burst damage. Therefore, based on nine-months seismic monitoring in a case study coal mine, this paper conducted a thorough analysis on quantifying ground motions to roadways in both far-field and near-field zones and correlating strong ground motions to actual coal burst damage. The results showed that most farfield ground motions were insignificant, which were less likely to initiate coal burst damage. However, with the same energy levels and hypocentral distances, the seismic events in coal mines can produce higher farfield ground motions than those in hard rock mines.
\end{abstract}

C. Wang · G. Si · C. Zhang $(\bowtie) \cdot$ I. Canbulat

School of Minerals and Energy Resources Engineering,

University of New South Wales, Sydney,

NSW 2052, Australia

e-mail: chengguo.zhang@unsw.edu.au

A. Cao

Key Laboratory of Deep Coal Resource Mining, Ministry of Education of China, China University of Mining and Technology, Xuzhou 221116, Jiangsu, China
Compared with the far-field ground motions, the nearfield ground motions had much higher intensities. The strong dynamic impacts induced by the near-field ground motions may trigger dynamic failure in coal or rock mass when it is already critically stressed. An index called the number of high ground motions $(N H G M)$ was developed to link ground motions with burst risks in roadways. The roadway zone that had experienced a long history of intensive ground motions, indicated by a higher degree of $N H G M$, were more likely to expect coal bursts in the future.

\section{Article highlights}

- Quantify ground motions to roadways in both farfield and near-field zones in underground coal mines.

- Demonstrate the relationship between ground motion intensity and coal burst damage.

- Develop a method to forecast potential burst damage zones in roadways based on historical ground motions.

Keywords Peak particle velocity - Coal burst . Seismic energy · Ground motion · Burst damage . Near-field · Far-field 


\section{Introduction}

Rockburst is a typical mining hazard, which describes an uncontrolled and violent ejection of rock fragments with excessive seismic energy after fracturing rock blocks (Cook 1965). It is referred to as coal burst in underground coal mines if the released seismic energy expels coal into mine openings (Zhang et al. 2017; Cai et al. 2019). Coal bursts and rockbursts in underground mines may cause significant damage to underground excavations and pose great threats to personnel, equipment and infrastructure. Since there is a large degree of variability and uncertainty in the causal factors, coal bursts and rockbursts are still the least understood and the most formidable of all mining hazards even after half a century of intensive research (Ortlepp 2005).

Mining-induced seismic events are normal responses to underground mining activities (Cao et al. 2018; Si et al. 2020). Ground motions and the induced dynamic impacts from these seismic events are one of the main factors to trigger coal and rockburst hazards (Cai et al. 2020). The ground motion intensity of a seismic event is commonly represented by peak particle velocity $(p p v)$, which is the maximum velocity of particle movement when a seismic wave travels in coal and rock mass (Qiu et al. 2021). For an underground excavation, its ground support can be easily affected by the dynamic impacts from ground motions in load, displacement and energy terms (Kaiser and Cai 2013a). The successive triggering from ground motions can cause cumulative fracturing in a highly stressed rock mass ( $\mathrm{Li}$ et al. 2019; Xie et al. 2020). The deepening fractures contribute to higher deviatoric stress and increase failure depth surrounding an excavation, which induces rock bulking and wall displacement (Martin et al. 1999; Kaiser et al. 2005; Cai and Kaiser 2018). Ground support in this condition must withstand this incremental deformation in the excavation, thus support elements with tensile deformation present a lower safety factor and an elevated vulnerability to coal and rockbursts (Kaiser and Cai 2013a). In hard rock mines, Kaiser (2006) proposed a linear relationship between failure depth around an excavation and ground motion intensities. For a strong seismic event with $p p v$ of $60-110 \mathrm{~mm} / \mathrm{s}$ and eight subsequent seismic events with $p p v$ between 20 to $50 \mathrm{~mm} / \mathrm{s}$, the total failure depth is estimated to be between 0.1 and
$0.15 \mathrm{~m}$ (Kaiser and Cai 2013a). Unfortunately, such studies have not been widely conducted in coal mines, and the depth failure estimation criterion in hard rock mines cannot be easily transferred to coal mines due to different mining environments and material properties. However, it is the truth that the historical ground motions are strongly related to coal and rock failures and excavation instability in burst-prone coal mines. Therefore, it is necessary to understand the ground motion characteristics of seismic events during mining in order to assess coal burst risks.

In previous research, ground motion intensities of strong seismic events in hard rock mines have been linked with rockbursts in many different countries (McGarr 1984; Kaiser 1996; Cai and Kaiser 2018). Intensive ground motions were observed in South African gold mines with $p p v$ values of between 0.3 to $2.3 \mathrm{~m} / \mathrm{s}$, which were induced by strong events of 3.8-4.1 in local magnitude occurred within $500 \mathrm{~m}$ of a mine (Glazer 2018). A seismic database of Canadian hard rock mines suggests that severe damage is commonly caused by ground motions with $p p v$ of larger than $0.6 \mathrm{~m} / \mathrm{s}$. Such intensive $p p v$ resulted from either a large scale event at far-field or a medium scale seismic event close to mine openings (Owen 2005). By conducting simulated rockburst experiments in deep South African hard rock mines, Milev (2005) found that $0.8 \mathrm{~m} / \mathrm{s}$ is the threshold to initiate burst damage in roadways. Up to now, coal mines that have provided the most detailed research findings on mining seismology are located in the Upper Silesian Coal Basin (USCB), Poland (Stec 2007; Ptáček 2017). The ground motion characteristics of coal burst in USCB have been concluded by Dou et al. (2016), which shows that a $p p v$ of $0.2 \mathrm{~m} / \mathrm{s}$ is the threshold to recognise apparent damage and $0.4 \mathrm{~m} / \mathrm{s}$ for potential hazard management. Mutke (2002) observed that more dynamic impacts from seismic events might be experienced in coal mines. With the same energy magnitude and hypocentral distance, most $p p v$ in coal seams is higher than that in hard rocks. However, it is rarely reported whether such intensive ground motions of coal bursts behave as the main contributor to stress change and energy release or just an additional trigger to already critically stressed rock (Bräuner 2017). Also, limited clues can be found to investigate the relationship between coal burst occurrence and cumulative impacts from historical events on roadways before the incident. 
In ground motion analysis, it cannot be ignored that seismic events adjacent to excavations may generate unexpected high ground motions (Roberts and Brummer 1988; Mutke 2002). Most of the burst damage is also reported very close to seismic sources. This phenomenon can be explained by the specific dynamic behaviour of a seismic event in its fractured zone, i.e. a near-field zone (Shearer 2009). Several ground motions in the near-field zone have been evaluated in hard rock mines in South Africa using synthetic seismograms or semi-empirical models from seismic monitoring results. In Mponeng and East Driefontein Mines in South Africa, the near-field $p p v$ was evaluated as $0.34-0.46 \mathrm{~m} / \mathrm{s}$, caused by seismic events in the local magnitude of 1.2-2.4 (Cichowicz 2001). Intensive near-field $p p v$ of up to $5.88 \mathrm{~m} / \mathrm{s}$ was recorded in a deep mine in the US at about $3 \mathrm{~km}$ depth (McGarr 1991). In the East Rand Proprietary Mines in South Africa (ERPM), a lower near-field $p p v$ was found from events of -0.76 to 1.40 in local magnitude, which ranges from $5.4 \times 10^{-4} \mathrm{~m} / \mathrm{s}$ to $6.25 \times 10^{-2} \mathrm{~m} / \mathrm{s}$ (McGarr et al. 1981). Ground motions in the nearfield zone have also been surveyed via specially designed sensors attached on the excavation surface, which can record high amplitude vibration induced by nearby events. Dubiński and Mutke (1996) summarised that the near-field $p p v$ in USCB coal mines is between 0.01 and $10 \mathrm{~m} / \mathrm{s}$, and the corresponding stress increase is from 0.1 to $50 \mathrm{MPa}$. It has been reported that in several hard rock mines in South Africa, nearfield $p p v$ driven by the failure of intact rock can be up to $3.0 \mathrm{~m} / \mathrm{s}$, and a dynamic stress drop on previously failed shear planes can cause a near-field $p p v$ of $0.1 \mathrm{~m} /$ s (Milev et al. 2002). However, due to the complicated calculation procedure and limitations in monitoring sensors, ground motions in near-field zones are still excluded in regular ground motion analysis, which becomes one of the major deficiencies for ground motion analysis that needs to be addressed (Kaiser and Cai 2013a). Since the enormous vibrations and potential damage to underground openings, the intensity of ground motions in near-field zones needs to be estimated and considered for coal burst forecasting and control.

Therefore, this paper investigated the ground motion characteristics of seismic events in both farfield and near-field zones, and further explored their relationships with the impending coal burst hazards. Based on the seismic data in a burst-prone coal mine, the ground motion intensities of seismic events and coal bursts were compared with the published data in other mines. By estimating dynamic stresses induced by ground motions, the triggering mechanism of coal burst damage was discussed. According to the cumulative damage that ground motions have caused to the surroundings of a mine opening, the link between historical ground motions and coal burst damage was established. A new index named the Number of High Ground Motions (NHGM) was also proposed to assess actual coal burst damage.

\section{Background}

\subsection{Near-field and far-field zones of seismicity}

The onset of a seismic event is associated with a stress drop and energy release on the ruptured plane, which is commonly assumed as a circular area with source radius $r_{0}$. There are significant differences in the rock deformation behaviour between the zones within and outside the source radius of a seismic event (see Fig. 1). Within $r_{0}$ to the source, the rock mass has permanent displacement and stress change. The intensive ground motions may even cause visible damage to the excavation. For the zone with a distance between $r_{0}$ and $2 r_{0}$ to the source, strong ground motions could cause a stress change that may affect adjacent fractures (Kaiser 1996). Therefore, a nearfield zone of a seismic event is defined as the zone within twice of its source radius. On the other hand, the far-field zone is defined as outside twice of the source radius. In the far-field zone, the radiated seismic waves from the source can only cause non-permanent displacement and stress change, and the ground motions are usually inversely proportional to the distance from the source. As a result, the types of ground motion that excavation undergoes depends on the distance between the excavation and the hypocenter of a seismic event. In this study, the source radius is estimated by an empirical equation proposed by Jager and Ryder (1999) based on the experience in South African underground mines:

$r_{0}=10^{\left(1+M_{L} / 2\right)} / 2$ 
Fig. 1 Characteristics of displacement and ground motion in rock mass at the near-field and far-field zones

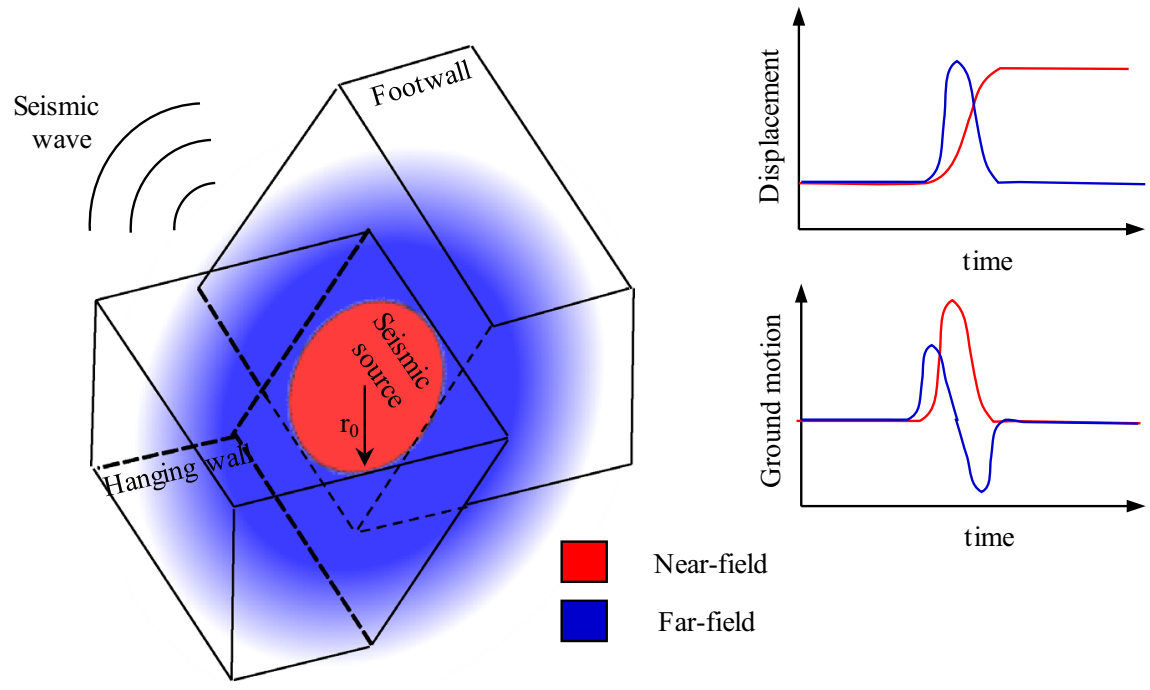

where $M_{L}$ is the local magnitude of the event. Based on Eq. 1, the source radii of seismic events range from 1 to $25 \mathrm{~m}$ when seismic energies range from 1 to $10,000 \mathrm{~kJ}$. As most of the seismic events in underground coal mines have energies around $100 \mathrm{~kJ}$, the equivalent source radii are commonly smaller than $5 \mathrm{~m}$.

\subsection{Ground motions in far-field zones}

Theoretically, ground motions induced by seismic events in far-field zones are positively related to the seismic energy and decay as the distance increases from the seismic source (Mendecki 1996; Shearer 2009). To approximate ground motion intensity of a seismic event in the far-field zone, $p p v R$ (unit: $\mathrm{m}^{2} / \mathrm{s}$ ) is usually used. $p p v R$ is the peak particle velocity ( $p p v)$ of the recorded seismic wave from geophones multiplied by the hypocentral distance $R$, the distance between the event and individual geophones in an array (Kaiser and Maloney 1997). Due to different source mechanisms, the wave radiation pattern of a seismic event in the far-field zone is complicated and directional, rather than in a simple spherical pattern, which causes different $p p v R$ readings among geophones (see Fig. 2a). For seismic risk assessment and ground support design, it is necessary to consider the most critical seismic loadings. Hence, only the (a)
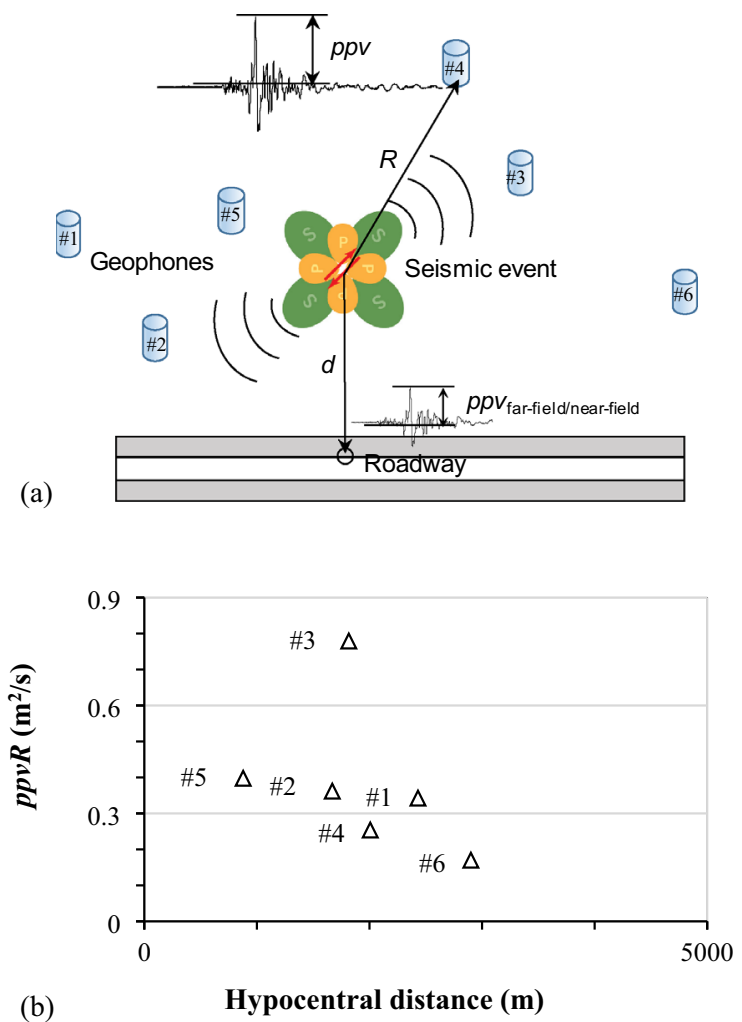

Fig. 2 a Schematic diagram of source mechanism of a seismic event, $p p v$ readings in different geophones and ground motions response in the roadway, $\mathbf{b}$ Example of $p p v R$ results of a seismic event from different geophones 
Fig. 3 a LW250105 layout and $\mathbf{b}$ stratigraphic column (a)

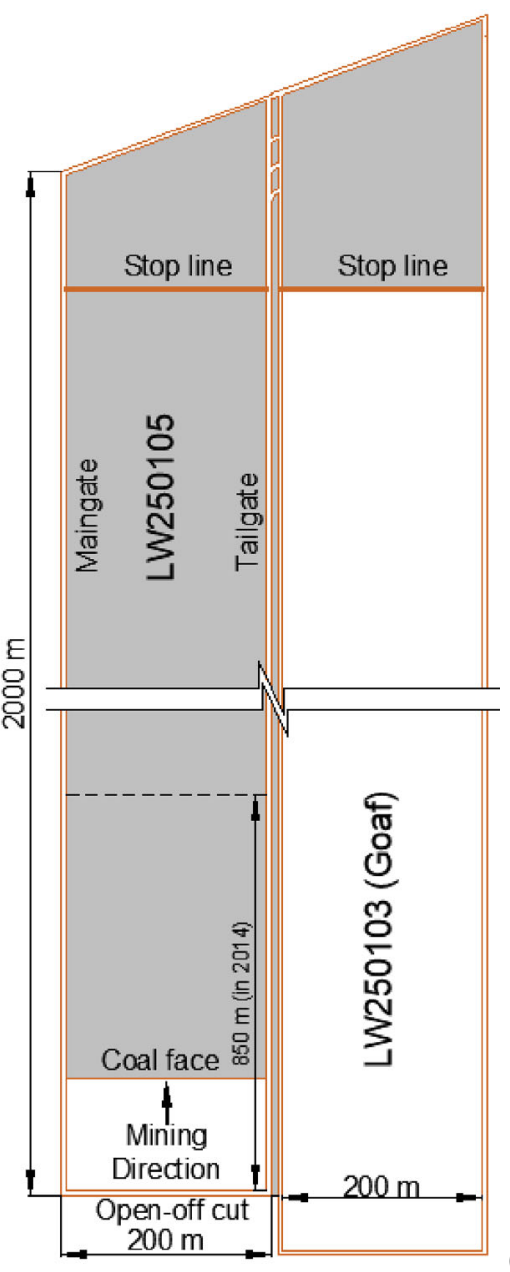

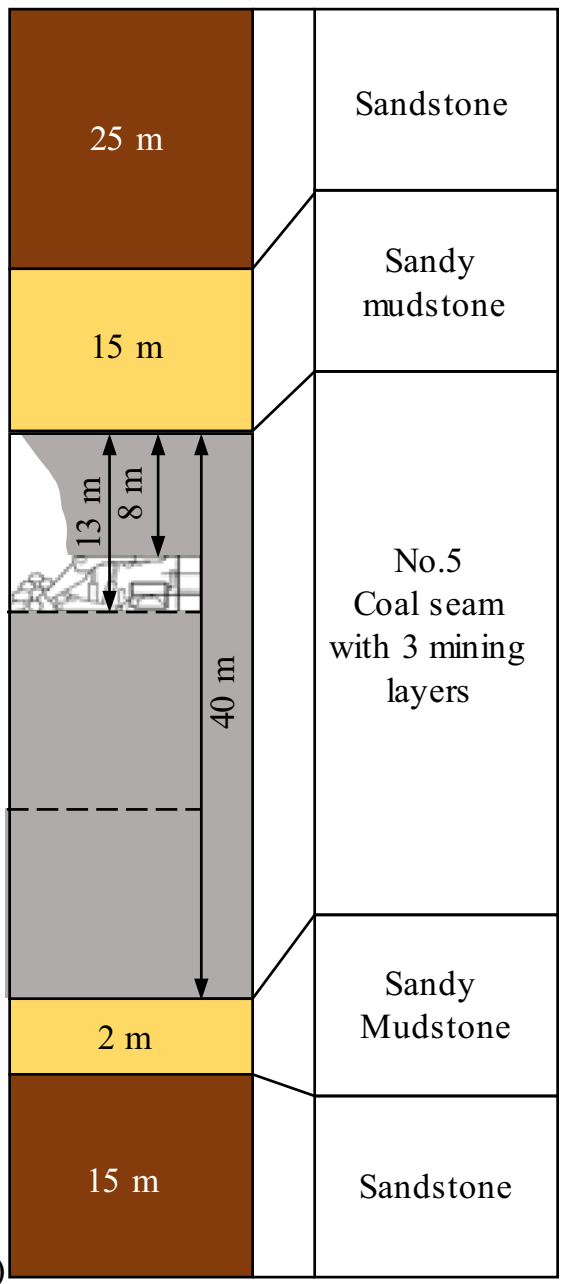

geophones that fully convey seismic energy in the maximum radiation direction are selected in this study (Kaiser and Cai 2013a). Figure 2b shows an example of $p p v R$ results of different geophones from a seismic event. Geophone \#3 has a higher $p p v R$ compared to others although its location is not the closest. This means, compared with other geophones, the seismic wave received by Geophone \#3 is most likely to be the peak or approximate to the peak of the radiation pattern. Thus the $p p v R$ recorded by Geophone \#3 is used to describe the ground motion intensity of this seismic event in the far-field zone. If an excavation is located in the far-field zone of a seismic event, the induced ground motion that the excavation undergoes, named as $p p v_{\text {far-field }}$, can be estimated using Eq. 2:

$p p v_{\text {far-field }}=\frac{p p v R}{d}$ where $d$ is the distance from a seismic event to the nearest roadway, or 'event-roadway distance' for short (see Fig. 2a).

\subsection{Ground motions in near-field zones}

As event-roadway distance is smaller than twice of the source radius, the excavation may experience intensive near-field ground motions. Due to the different radiation and attenuation characteristics, the intensity of a seismic event in the near-field zone cannot be simply described as $p p v R$. Although it is difficult to directly measure near-field ground motions, it is possible to have an estimation by using analytical equations derived from synthetic seismograms or/and semi-empirical models. In this study, the method proposed by McGarr (1991) is adopted, which relates 

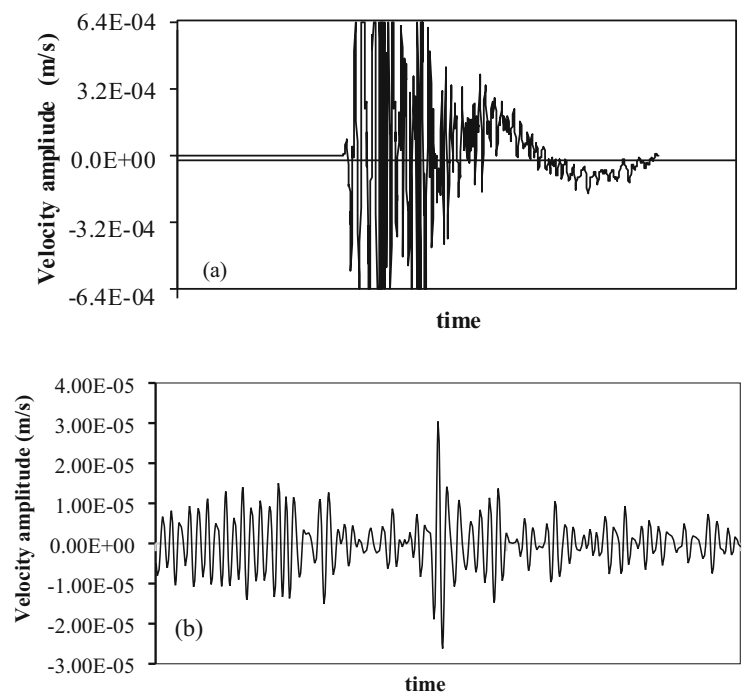

Fig. 4 Examples of waveforms captured by a roadway geophones and $\mathbf{b}$ distant geophones

near-field ground motion to geophone recordings. Within the near-field zone of a seismic event, there are many asperities on the rupture plane. Each asperity failure can be regarded as a sub-event producing one single sine seismic wave (Boatwright 1988). The patterns of seismic waves from geophone readings are thus the combination of sine waves from multiple asperity failures. The ground motion in each asperity failure, i.e. near-field ground motion, equals half of its slip velocity, which is the velocity of one side of the asperity with respect to the other side (Mendecki 2016). The maximum slip velocity of the asperities can be calculated using hypocentral distance $R$ and peak particle acceleration (ppa), which is the derivative of velocity waveforms from geophone readings. After considering the above factors, for an excavation located in the near-field zone of an event, the ground motion (hereafter referred to as $p p v_{\text {near-field }}$ ) can be calculated by Eq. 3 (McGarr 1991):

$p p v_{\text {near-field }}=1.28\left(C_{s} / G\right) \rho R p p a$ where $C_{S}$ is shear wave velocity, $\rho$ is rock density, and $G$ is rock shear modulus. As the near-field ground motion is directly induced by the local rock failure, it can be used as an indicator to describe failure intensity.

\section{Overview of the case study site}

\subsection{Geology}

The case study site, Huating Coal Mine, is a typical burst-prone coal mine in Gansu Province, China. Over 200 coal bursts have been reported since 2008. According to the regional in-situ stress measurements, the in-situ stress is dominated by horizontal stress in this mine, which is approximately 1.2 times the vertical stress (Ju et al. 2019). The target coal seam to be extracted is No. 5 Coal Seam, which is 550-800 $\mathrm{m}$ deep with a dip angle between $1^{\circ}$ and $15^{\circ}$. The coal seam has an average thickness of about $40 \mathrm{~m}$. Thus, it is designed to be mined out in three slices, and the longwall top coal caving method is used for each layer (see Fig. 3b). The mining height in each layer is $13 \mathrm{~m}$, including $5 \mathrm{~m}$ in cutting and $8 \mathrm{~m}$ in caving.

The study longwall panel LW250105, is the upper layer panel of No. 5 Coal Seam, with a length of 2,000 $\mathrm{m}$ and a width of $200 \mathrm{~m}$ (see Fig. 3a). The panel started to retreat from the start-up position in March 2014 and stopped at the completion position in May 2016. LW250105 is overlaid by $15 \mathrm{~m}$ and $25 \mathrm{~m}$ thick sandy mudstone and sandstone units, respectively. Different from conventional mine designs, the tailgate of LW250105 was developed using the "gob-side entry driving" method (GED) (Wu et al. 2018). This method aims to reduce the coal losses in wide chain pillars in order to meet the minimum recovery ratio requirement. As a result, only a $6 \mathrm{~m}$-wide rib pillar was left between LW250105 tailgate and the goaf created by the previous longwall panel, LW250103.

Table 1 Mechanical properties of coal and rock mass in LW250105

\begin{tabular}{llllll}
\hline Wave velocity (average) & & Coal uniaxial compression strength (UCS) & Coal density $(\rho)$ & Coal shear modulus $(G)$ \\
\hline P-wave $\left(C_{s}\right)$ & S-wave $\left(C_{p}\right)$ & & & \\
\hline $3600 \mathrm{~m} / \mathrm{s}$ & $2080 \mathrm{~m} / \mathrm{s}$ & $13.7 \mathrm{MPa}$ & $1320 \mathrm{~kg} / \mathrm{m}^{3}$ & $1.15 \mathrm{GPa}$ \\
\hline
\end{tabular}


Table 2 Coal bursts characteristics in LW250105

\begin{tabular}{|c|c|c|c|c|c|c|c|c|}
\hline No. & Date & $\begin{array}{l}\text { Seismic } \\
\text { energy }(\mathrm{kJ})\end{array}$ & $\begin{array}{l}p p v R \\
\left(\mathrm{~m}^{2} / \mathrm{s}\right)\end{array}$ & $\begin{array}{l}\text { Local } \\
\text { magnitude }\end{array}$ & $\begin{array}{l}\text { Source } \\
\text { radius (m) }\end{array}$ & $\begin{array}{l}\text { Damage length } \\
\text { of roadway }(\mathrm{m})\end{array}$ & $\begin{array}{l}\text { Epicentral distance } \\
\text { from coal burst to } \\
\text { damage zone }(\mathrm{m})\end{array}$ & $p p v_{\text {near-field }}(\mathrm{m} / \mathrm{s})$ \\
\hline 1 & 8-Apr & 28,600 & 1.08 & 1.78 & 38.41 & 60 & 135 & 0.77 \\
\hline 2 & 13-Apr & 180 & 0.19 & 0.30 & 7.10 & 20 & 8 & 0.03 \\
\hline 3 & 17-Apr & 770 & 0.42 & 0.72 & 11.50 & 60 & 98 & 0.04 \\
\hline 4 & 24-Apr & 1860 & 0.50 & 0.98 & 15.46 & 30 & 42 & 0.23 \\
\hline 5 & 29-Apr & 2960 & 0.80 & 1.11 & 18.03 & 32 & 90 & 0.27 \\
\hline 6 & 27-May & 1220 & 0.37 & 0.86 & 13.42 & 40 & 29 & 0.20 \\
\hline 7 & 3-Jun & 2350 & 0.63 & 1.05 & 16.70 & 20 & 14 & 0.08 \\
\hline 8 & 27-Jun & 1780 & 0.57 & 0.97 & 15.22 & 60 & 27 & 0.28 \\
\hline 9 & 10-Jul & 1780 & 0.78 & 0.97 & 15.22 & 40 & 104 & 0.03 \\
\hline 10 & 29-Jul & 94 & 0.18 & 0.12 & 5.71 & 20 & 47 & 0.09 \\
\hline 11 & 2-Aug & 180 & 0.45 & 0.31 & 7.13 & 40 & 140 & 0.01 \\
\hline 12 & 6-Sep & 340 & 0.24 & 0.49 & 8.75 & 30 & 17 & 0.14 \\
\hline 13 & 7-Sep & 550 & 0.45 & 0.63 & 10.30 & 60 & 27 & 0.22 \\
\hline 14 & 12-Sep & 130 & 0.41 & 0.21 & 6.39 & 30 & 15 & 0.05 \\
\hline 15 & 15-Sep & 470 & 0.29 & 0.58 & 9.79 & 30 & 44 & 0.12 \\
\hline 16 & 16-Sep & 1110 & 0.42 & 0.83 & 13.00 & 30 & 0 & 0.21 \\
\hline 17 & 22-Sep & 88 & 0.12 & 0.10 & 5.58 & 30 & 0 & 0.02 \\
\hline 18 & 27-Sep & 620 & 0.40 & 0.66 & 10.68 & 20 & 28 & 0.05 \\
\hline 19 & 6-Oct & 53 & 0.22 & -0.05 & 4.72 & 22 & 16 & 0.01 \\
\hline 20 & $11-$ Oct & 1860 & 0.53 & 0.98 & 15.45 & 50 & 65 & 0.05 \\
\hline 21 & $25-\mathrm{Oct}$ & 57 & 0.16 & -0.03 & 4.84 & 19 & 145 & 0.09 \\
\hline 22 & 16-Nov & 140 & 0.25 & 0.22 & 6.44 & 20 & 10 & 0.11 \\
\hline 23 & 3-Dec & 170 & 0.30 & 0.28 & 6.92 & 40 & 148 & 0.77 \\
\hline 24 & 13-Dec & 1320 & 0.34 & 0.88 & 13.78 & 20 & 46 & 0.03 \\
\hline
\end{tabular}

The rib had limited loading capacity and was mainly used to insulate the tailgate and goaf. The rib width was determined based on the distribution of abutment stresses induced by longwall retreat on the goaf-side coal seam. The tailgate was designed to be in the "destressed zone" to avoid stress-induced damage and ensure its stability (Bai et al. 2015). Although GED method has been applied in several Chinese coal mines (Zhong et al. 2012; Jia et al. 2014; Qian et al. 2014), the LW250105 tailgate experienced high risks of coal burst caused by strata breakage and strong ground motions.

\subsection{Seismic monitoring system}

The seismic activity in Huating Coal Mine was continuously monitored by a total of 16 single vertical-component geophones in the mine. Six geophones were installed in the tailgate and the maingate, which are named roadway geophones and moved along with the retreating face. Since these roadway geophones are near to the seismically active zone, the waveforms received by them usually have large amplitude and little noise. As the high waveform amplitude may be beyond the geophone measurement range of $\pm 0.64 \mathrm{~mm} / \mathrm{s}$, some seismic signals are truncated by the roadway geophones thus the recorded waveform are incomplete (see Fig. 4a). Hence the roadway geophones are mainly used for locating seismic events by picking up a clear P-wave arrival time. Another ten geophones are named distant geophones, which were placed 2-4 km away from the working face. Due to the attenuation over the longdistance, most of the waveforms received by the distant geophones are complete with amplitudes within the geophone measurement range. Thus, the 
Fig. 5 Coal burst locations and damage areas in LW250105 between April 2014 to December 2014

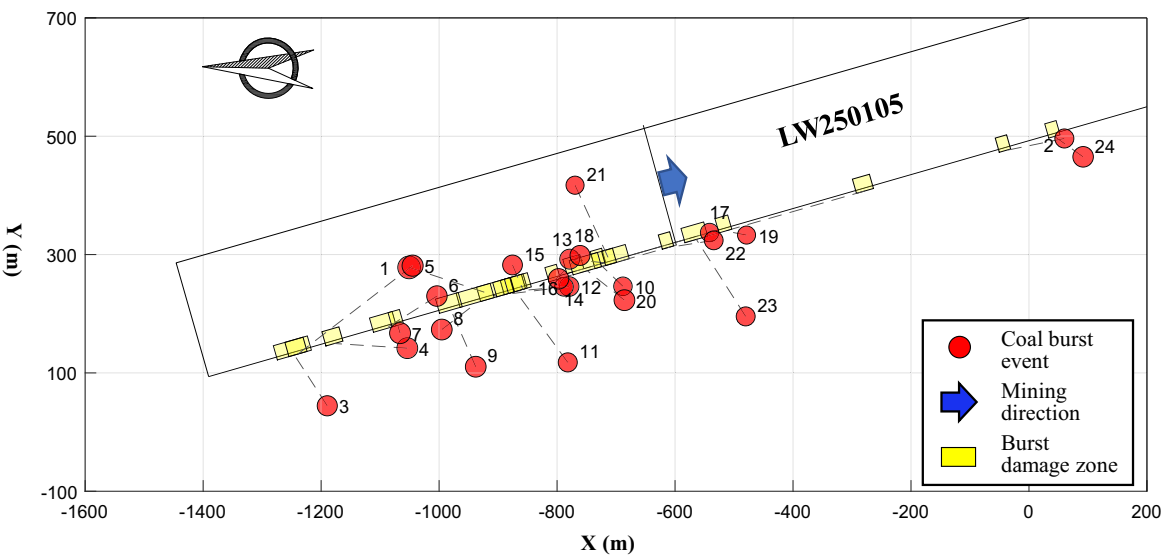

distant geophones are mainly used for source parameter calculation. However, because of the goaf and geological structures that seismic waves may pass through, the waveforms recorded from the distant geophones are commonly mixed with more noise than those of the roadway geophones (see Fig. 4b). Because the seismic monitoring for LW250105 only commenced in April 2014, seismic events and coal bursts between April and December 2014 were used for this paper.

Several mechanical properties used for ground motion analysis are shown in Table 1 . The seismic wave velocity is calculated and calibrated by in-situ seismic monitoring for locating purposes. The uniaxial compressive strength of the coal (UCS), coal density and shear modulus are derived from laboratory tests. The test results in Table 1 are the average values.

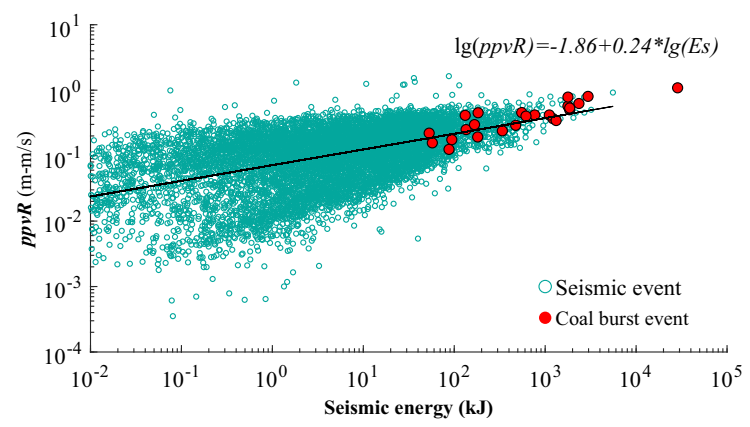

Fig. 6 Relationship between seismic energy and $p p v R$ of seismic events and coal bursts in LW250105

\subsection{Coal bursts}

During the study period, LW250105 had 24 coal bursts recorded on the tailgate side, and their characteristics are listed in Table 2. These coal bursts have seismic energy magnitudes ranging from 87.6 to $28,600 \mathrm{~kJ}$, and their expected source radii are between 4.72 and $38.41 \mathrm{~m}$. The burst-induced roadway damage included instantaneous floor heave, rib convergence, and ground support failure. The damage areas covered most of the tailgate, with lengths ranging from 20 to $60 \mathrm{~m}$, and many of them experienced burst damage more than once (see Fig. 5). It indicates that highstress concentration around roadway surroundings had not been sufficiently released after coal bursts and rebuilt rapidly during progressive mining activities. This is in contrary to the believe that it cannot burst again once the rock mass is damaged. Further failure is considered to have occurred in the elastic zones outside the damaged zones.

According to Sect. 2.1, damage zones experienced ground motions from coal bursts in either far-field or near-field zone, which are analogous to the terms 'indirect burst' and 'direct burst' in other researchers' work (Gibowicz and Kijko 1994). If coal bursts located far away from the roadway, the induced ground motions in the far-field zone play a role of triggering damage in the high-stress area around the roadway. For roadways located in the near-field zone of coal bursts, the instant fractures and rock failures within the near-field zone of the source can directly cause violent vibrations and severe burst damage. In this condition, coal bursts could be the source of the roadway damage rather than a trigger (Kaiser and Cai 

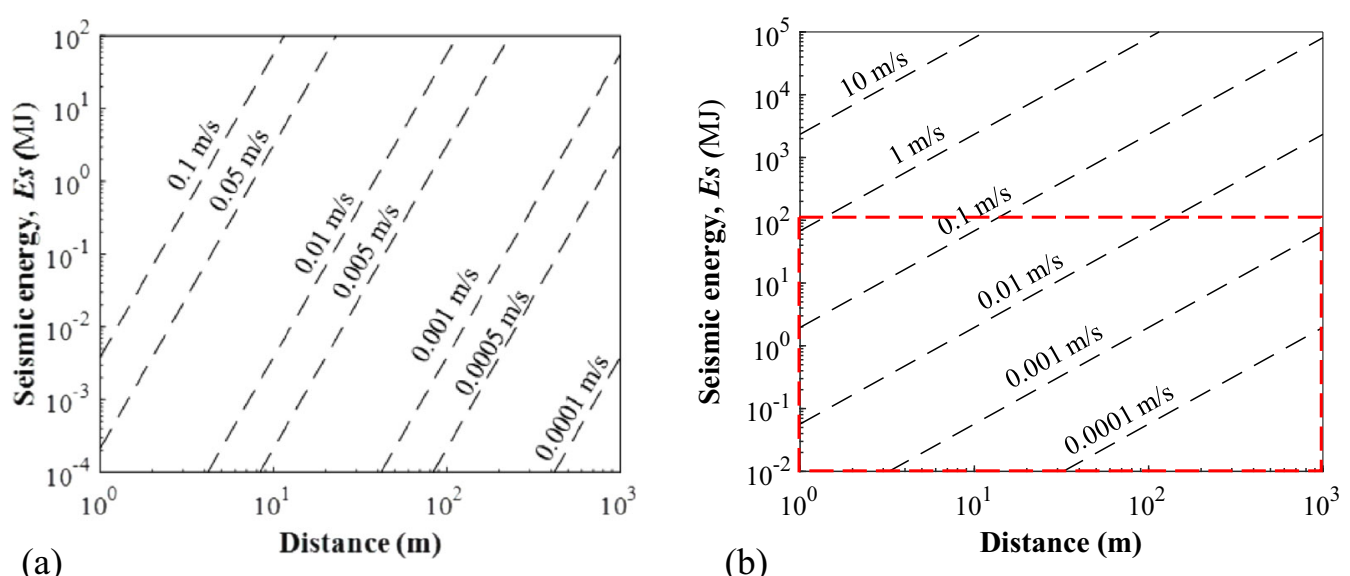

Fig. 7 Average ground motion intensities in far-field zones of seismic events in a LW250105 and b gold mines in Klerksdorp Goldfield (Glazer 2018)

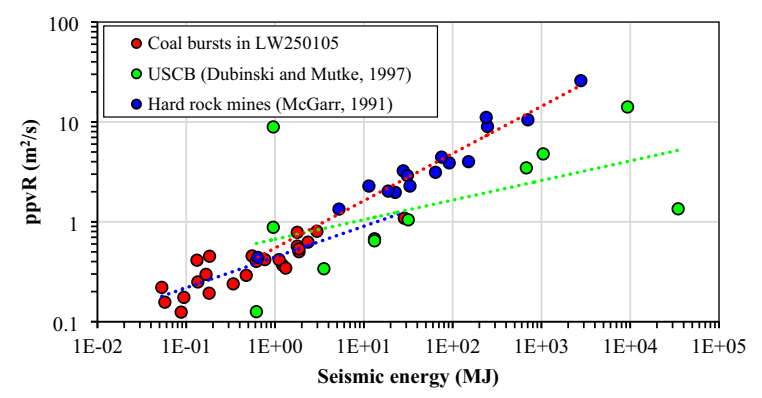

Fig. 8 Relationship between $p p v R$ and seismic energy of LW250105 coal bursts (marked with red), coal bursts in USCB (marked with green) and strong seismic events in hard rock mines (marked with blue)

2013b). Based on the source radii and epicentral distances to damage zones (see Table 2), most of the coal bursts were reported close to the damage zones in the tailgate (see Fig. 5). It means that many of the coal bursts could occur near the damage zone and cause near-field ground motions. To investigate the impacts of coal bursts to roadway damage, ground motions of coal bursts in both the far-field and near-field zones were investigated.

\section{Ground motion characteristics in LW250105}

\subsection{Ground motions in the far-field zones}

Nearly 10,000 seismic events in LW250105 are recognised as causing ground motions in far-field zones to the roadway. Figure 6 shows the relationship between $p p v R$ and seismic energies. The $p p v R$ of seismic events ranges from $3.1 \times 10^{-5} \mathrm{~m}^{2} / \mathrm{s}$ to $1.6 \mathrm{~m}^{2} /$ $\mathrm{s}$. The highest $p p v R$ is from a seismic event with energy magnitude of $87 \mathrm{~kJ}$, located $45 \mathrm{~m}$ away from the roadway. In this paper, the scaling law is used to indicate the relationship between $p p v$ and seismic source intensity as a function of the distance $R$ from the source (Perret 1972; McGarr 1984; Kaiser and Maloney 1997). According to the scaling law, the relationship between average $p p v R$ and seismic energy $\left(E_{S}\right)$ can be determined using the least-squares regression line in Fig. 6:

$\lg (p p v R)=0.24 \lg \left(E_{S}\right)-1.86$

Based on Eq. 4, a scaling correlation map was plotted in Fig. 7a showing the average ground motion intensities in the far-field zone with varying seismic energies and hypocentral distances. For example, a seismic event with $1 \mathrm{~kJ}$ energy is expected to induce $0.001 \mathrm{~m} / \mathrm{s} p p v$ at about $80 \mathrm{~m}$ away from the source. To compare the differences of ground motion intensities between coal mines and hard rock mines, the ground motion intensities recorded at hard rock mines, the gold mines in Klerksdorp Goldfield, South Africa (Glazer 2018), are also presented in Fig. 7b. Due to the higher magnitude of seismic energies, ground motions of more than $1 \mathrm{~m} / \mathrm{s}$ could be experienced in hard rock mines. However, with the same energy level and hypocentral distance (shown as the zone with the red dashed line in Fig. 7b), seismic events in coal mines can produce higher ground motions than that in hard rock mines. For example, to induce ground motions of 


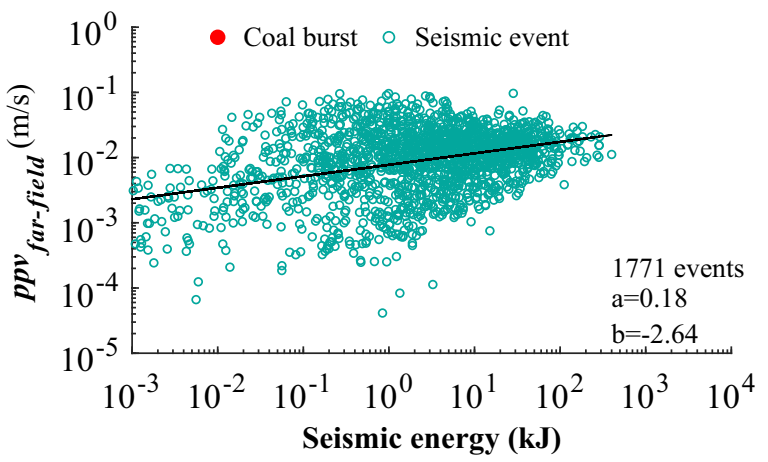

(a) $d<20 \mathrm{~m}$

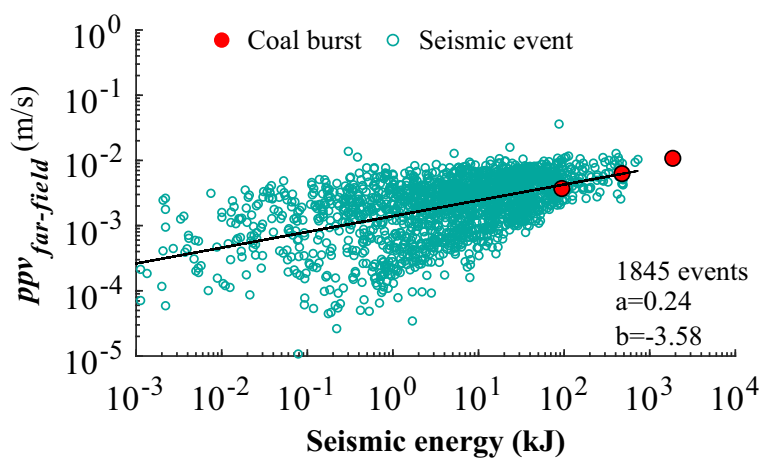

(c) $40 \mathrm{~m}<d<60 \mathrm{~m}$

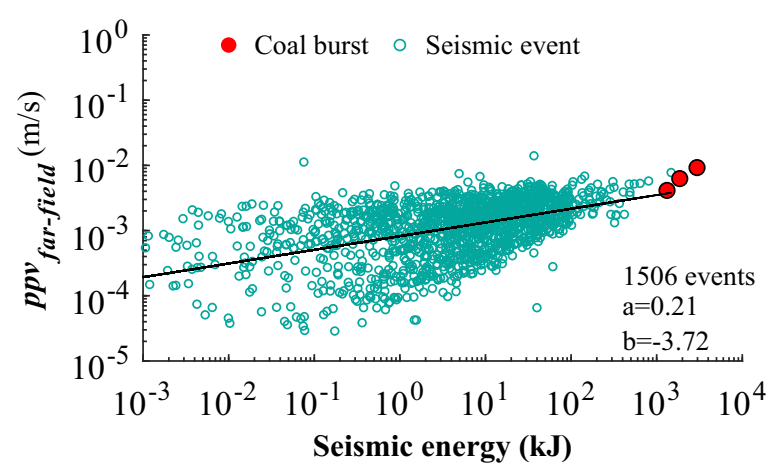

(e) $80 \mathrm{~m}<d<100 \mathrm{~m}$

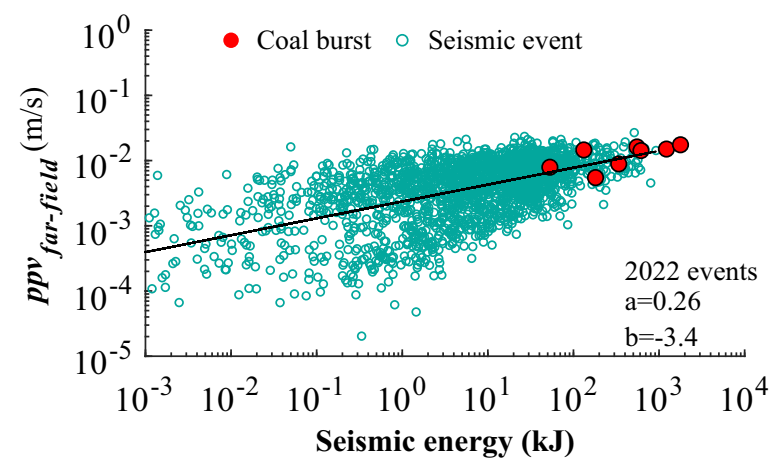

(b) $20 \mathrm{~m}<d<40 \mathrm{~m}$

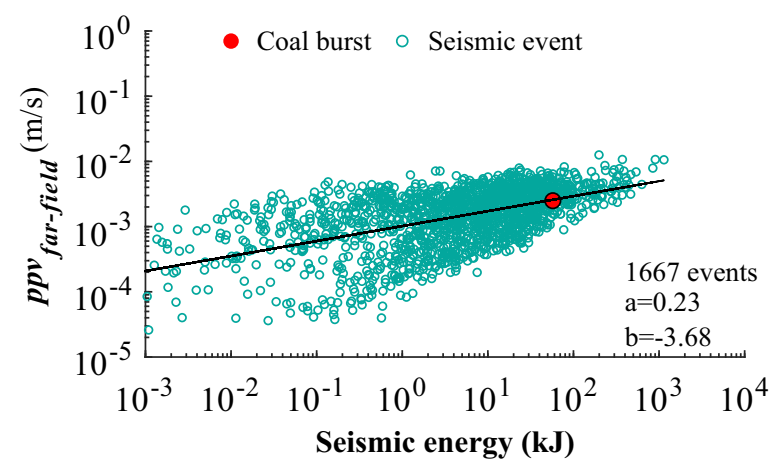

(d) $60 \mathrm{~m}<d<80 \mathrm{~m}$

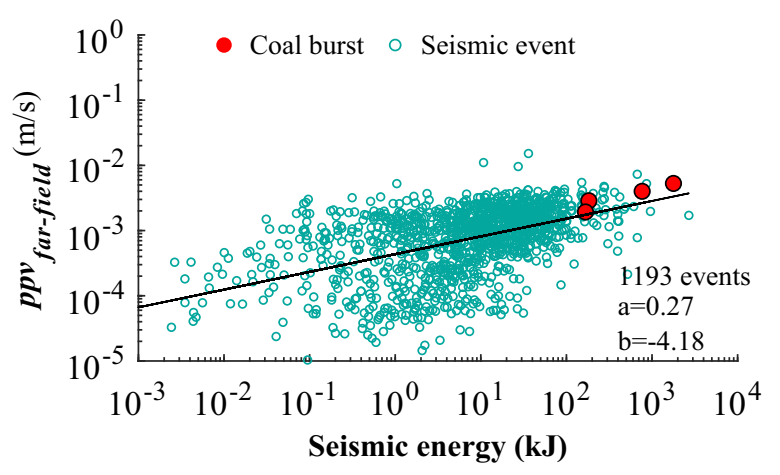

(f) $d>100 \mathrm{~m}$

Fig. 9 Far-field ground motions from seismic events (marked as blue dotes) and coal bursts (marked as red dotes) at different eventroadway distances $(d)$

$0.01 \mathrm{~m} / \mathrm{s}$ from $10 \mathrm{~m}$ away from the source, a seismic event should have energies of $1 \mathrm{MJ}$ in hard rock mines but only about $10 \mathrm{~kJ}$ in LW250105. It means that for the same ground motion level, the energy of seismic events in coal mines can be as much as 100 times higher than that in hard rock mines.
The $p p v R$ of studied coal bursts in LW250105 ranges from 0.12 to $1.09 \mathrm{~m}^{2} / \mathrm{s}$, which only shows a moderate intensity compared to that of seismic events with similar energy level. Figure 8 displays $p p v R$ intensities between LW250105 coal bursts (marked with red), USCB coal bursts concluded by Dubinski 


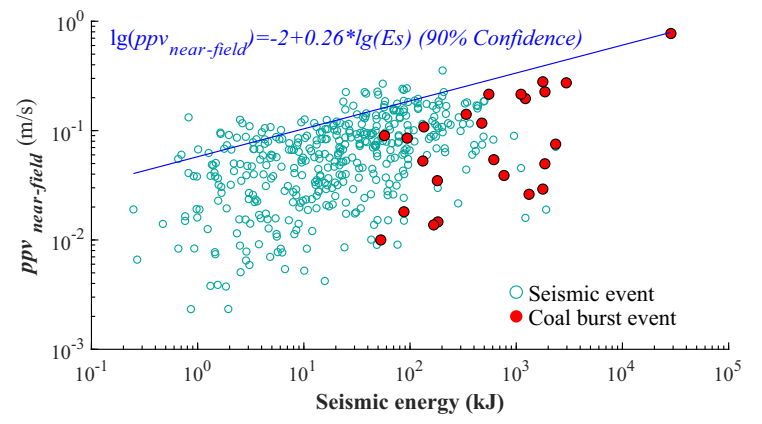

Fig. 10 Relationship between seismic energy and near-field ground motions in LW250105

and Mutke (1997) (marked with green) and rockbursts summarised by McGarr (1991) (marked with blue). USCB coal bursts cover a broad range of energy level from $0.6 \mathrm{~kJ}$ to more than $34,000 \mathrm{MJ}$, and the maximum $p p v R$ is $14.13 \mathrm{~m}^{2} / \mathrm{s}$. Rockbursts have an overall higher energy level than coal bursts, and the maximum $p p v R$ can be up to $25.9 \mathrm{~m}^{2} / \mathrm{s}$. Compared to USCB coal bursts and rockbursts, the coal bursts recorded in LW250105 have lower energy levels and $p p v R$ intensities. This suggests that the coal bursts in LW250105 were more easily triggered by seismic events than that in other mines in the literature.

Figure 9 shows the $p p v_{\text {far-field }}$ induced by seismic events and coal bursts in different ranges of eventroadway distances. The $p p v_{\text {far-field }}$ of seismic events ranged from $2.16 \times 10^{-6} \mathrm{~m} / \mathrm{s}$ to $0.10 \mathrm{~m} / \mathrm{s}$, and the maximum $p p v_{\text {far-field }}$ was induced by a $28 \mathrm{~kJ}$ event which occurred $12.61 \mathrm{~m}$ away from the roadway. The $p p v_{\text {far-field }}$ of coal bursts ranged from $1.93 \times 10^{-3} \mathrm{~m} / \mathrm{s}$ to $0.017 \mathrm{~m} / \mathrm{s}$, with event-roadway distances varying from 24 to $157 \mathrm{~m}$. Although the average $p p v_{\text {far-field }}$ of coal bursts is higher than $80 \%$ of seismic events, the peak $p p v_{\text {far-field }}$ is still lower than that of nearly 600 seismic events, constituting more than $5 \%$ of the total. Most of the intensive $p p v_{\text {far-field }}$ of higher than $0.01 \mathrm{~m} /$ $\mathrm{s}$ were induced by the events located within $20 \mathrm{~m}$ to the roadway (see Fig. 9a). Few intensive $p p v_{\text {far-field }}$ were observed from events located more than $40 \mathrm{~m}$ from the roadway (see Fig. 9c, d, e, f).

The trend of ground motions in each eventroadway distance range can be represented by a power-law relationship:

$\lg p p v=a \lg E_{S}+b$ where $a$ is the slope of the fitted trendline, indicating the difference of ground motions between events at different energy levels. $b$ is the intercept/cut-off of the trendline showing an overall ground motion level. The black lines in Fig. 9 are the best-fit power-law trendlines between $p p v_{\text {far-field }}$ and seismic energy. The result shows a lower $a$ and a higher $b$ in Fig. 9a than that in Fig. $9 b \sim$ f. It indicates that seismic events located less than $20 \mathrm{~m}$ from the roadway have generally higher $p p v_{\text {far-field, }}$, which also cover a high energy magnitude range. For example, $p p v_{\text {far-field }}$ larger than $0.01 \mathrm{~m} / \mathrm{s}$ can be induced by these seismic events with an energy level from only $0.02-400 \mathrm{~kJ}$. It implies that ground motions in the far-field zone induced by a seismic event closer to the roadway can be more intensive and less influenced by seismic energy. Figure $9 \mathrm{~b} \sim \mathrm{f}$ also shows that the $p p v_{\text {far-field }}$ induced by certain coal bursts are even lower than many of the seismic events with the same energy levels. The results imply that most of the $p p v_{\text {far-field }}$ of seismic events and coal bursts are far below the risky ground motions criterion in USCB, i.e. $0.2 \mathrm{~m} / \mathrm{s}$ (Dou et al. 2016). Therefore, it can be postulated that the coal bursts in LW250105 were less likely initiated by ppv $v_{\text {far-field }}$.

\subsection{Ground motions in the near-field zones}

410 seismic events were found to produce ground motions to roadways in the near-field zone, including 83 events to the maingate and 327 to the tailgate. Figure 10 is the $p p v_{\text {near-field }}$ results of these seismic events and the studied coal bursts. The seismic events produced $p p v_{\text {near-field }}$ from $7.64 \times 10^{-4} \mathrm{~m} / \mathrm{s}$ to $0.35 \mathrm{~m} /$

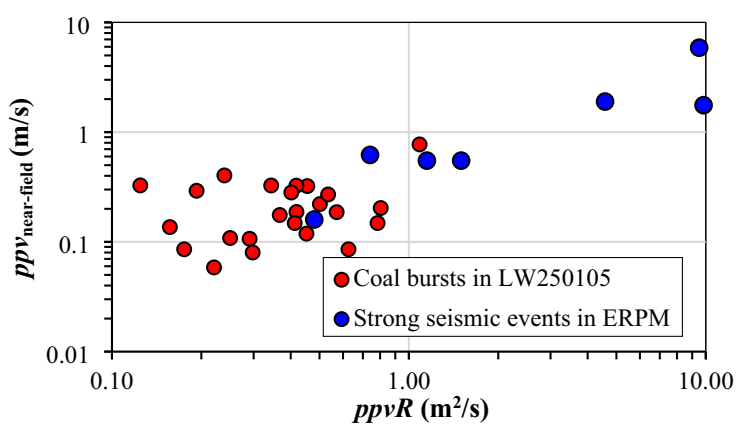

Fig. 11 Ground motions in near-field zones of LW250105 coal bursts (marked with red) and hard rock mines in South Africa (marked with blue) 
$\mathrm{s}$, with a large energy magnitude ranging from 0.25 to $2350 \mathrm{~kJ}$. The average $p p v_{\text {near-field }}$ is $0.076 \mathrm{~m} / \mathrm{s}$, which is nearly 20 times higher than the average $p p v_{\text {far-field, }}$, $5.0 \times 10^{-3} \mathrm{~m} / \mathrm{s}$. For the purpose of hazard forecasting and control, we focus more on the highest ground motion in extreme conditions at each energy level. Therefore, the upper bound limit of $p p v_{\text {near-field }}$ at $90 \%$ confidence was plotted as a blue line in Fig. 10, and this boundary can be defined in the following equation:

$$
\begin{aligned}
\lg \left(\text { ppv } v_{\text {near-field }}\right)= & -2.0 \\
& +0.26 \lg \left(E_{S}\right) \quad(90 \% \text { confidence })
\end{aligned}
$$

Based on Eq. 6, a seismic event with $1 \mathrm{~kJ}$ energy can potentially produce $0.06 \mathrm{~m} / \mathrm{s} p p v_{\text {near-field, }}$, and a seismic event with $1000 \mathrm{~kJ}$ energy is expected to have up to $0.36 \mathrm{~m} / \mathrm{s} p p v_{\text {near-field. }}$.

Due to the higher energy magnitude and peak particle acceleration in the seismogram, coal bursts produced more intensive near-field ground motions than seismic events. $p p v_{\text {near-field }}$ of coal bursts ranged from $0.01 \mathrm{~m} / \mathrm{s}$ to $0.77 \mathrm{~m} / \mathrm{s}$, and the average is $0.13 \mathrm{~m} /$ s. Similar results were presented by Cichowicz (2001) and McGarr et al. (1981), which suggest that the ground motions in the near-field zone can vary from $5.4 \times 10^{-4} \mathrm{~m} / \mathrm{s}$ to $0.46 \mathrm{~m} / \mathrm{s}$. The most intensive ground motion in the near-field zone was induced by the coal burst on 8 April 2014, which released seismic energy of 28,600 kJ and caused $60 \mathrm{~m}$-long damage in the LW250105 tailgate. Compared with the hazardous seismic events at the East Rand Proprietary Mines in South Africa (McGarr 1991), the overall $p p v_{\text {near-field }}$ of the coal bursts is lower than that of hazardous events in hard rock mines (see Fig. 11).

Figure 12 shows the result of average intensities of ground motions in both far-field and near-field zones and the number of events in different ranges of eventroadway distances. From this figure, there is no general trend of the average ground motions in the near-field zone along with the increase of eventroadway distance. The peak average $p p v_{\text {near-field }}$ of $0.13 \mathrm{~m} / \mathrm{s}$ was induced by the seismic events with event-roadway distances between 10 and $20 \mathrm{~m}$, rather than the ones with event-roadway distances less than $10 \mathrm{~m}$. It indicates that the zone with event-roadway distances between 10 and $20 \mathrm{~m}$ was under intensive static loads, since the failure of the critically stressed rock mass is more likely to accelerate vibrations and cause higher ground motions in the near-field zone (Mendecki 2016). For all the ranges of event-roadway distances, the average $p p v_{\text {far-field }}$ is much lower than

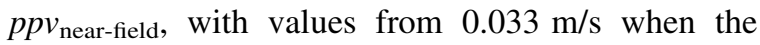
event-roadway distance is less than $10 \mathrm{~m}$ to $0.002 \mathrm{~m} / \mathrm{s}$ when the event-roadway distance is larger than $40 \mathrm{~m}$.
Fig. 12 Average far-field and near-field ground motions and number of events at different eventroadway distances

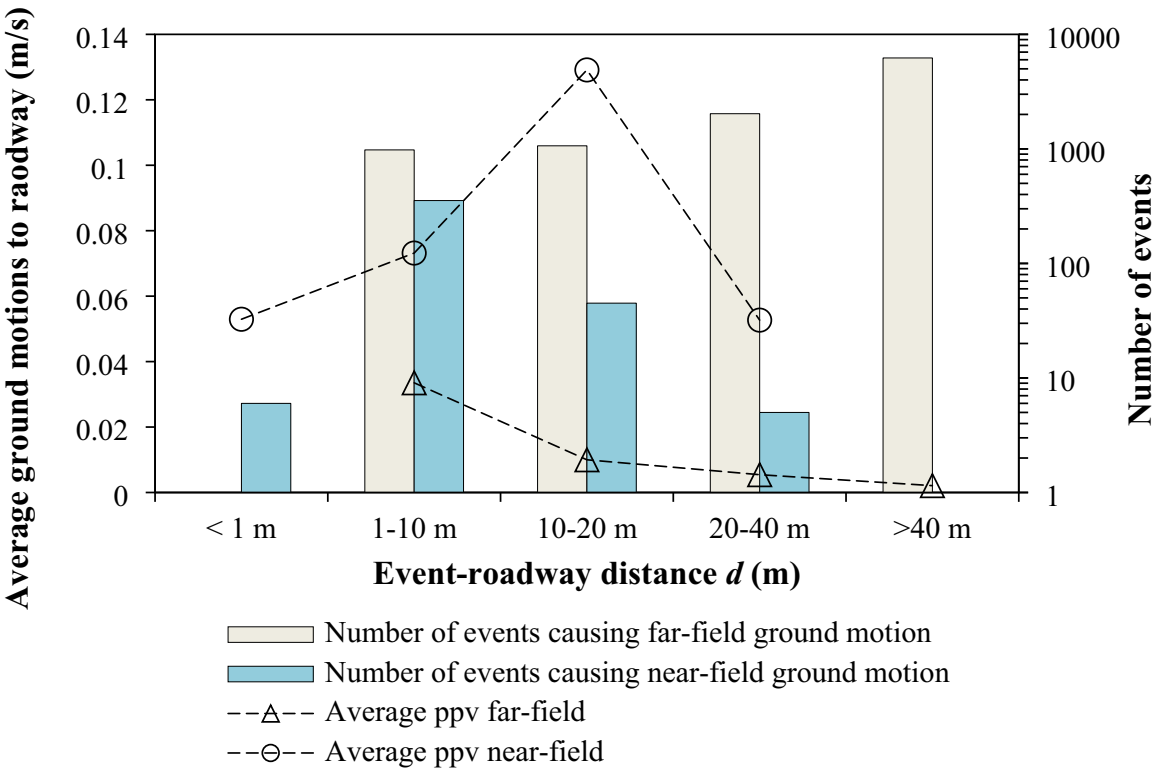




\subsection{Dynamic stress}

The equivalent dynamic stress induced by ground motions to the roadway can be estimated by Eq. 7 (Kaiser 1996):

$\Delta \sigma^{d}=n C_{S} \rho \cdot p p v$.

In this equation, $\rho$ is the material density, $C_{S}$ is the shear wave velocity in the material, $n$ is a constant ranging from -4 to 4 , which is related to wave incidence angle. Since the most unfavourable conditions should be firstly considered for burst risk management in mines, $n$ equal to 4 is adopted, which represents $45^{\circ}$ incidence of the seismic wave relative to the maximum principal stress (Kaiser 1996).

Figure 13 shows the results of dynamic stresses induced by ground motions from seismic events and coal bursts, and the coal UCS (uniaxial compression strength) here is used as a reference. It shows that most of the low-intensity dynamic stresses are induced by ground motions in the far-field zone, and mediumhigh intensity dynamic stresses are dominated by ground motions in the near-field zone. Nearly $80 \%$ of the seismic events, with ground motions to roadways less than $0.009 \mathrm{~m} / \mathrm{s}$, induced dynamic stresses less than 0.1 MPa. Such a low transient stress increment in coal can be ignored if compared to the coal UCS, 13.7 MPa. Only top $1 \%$ ground motions produced dynamic stresses more than $10 \%$ of coal UCS, 1.37 MPa. Considering that the strength of the coal mass is commonly lower than UCS due to the natural jointing and fracturing, such intensity of dynamic stresses is likely to initiate the instability and failure of critically stressed coal. The maximum dynamic stresses of ground motions that seismic events and

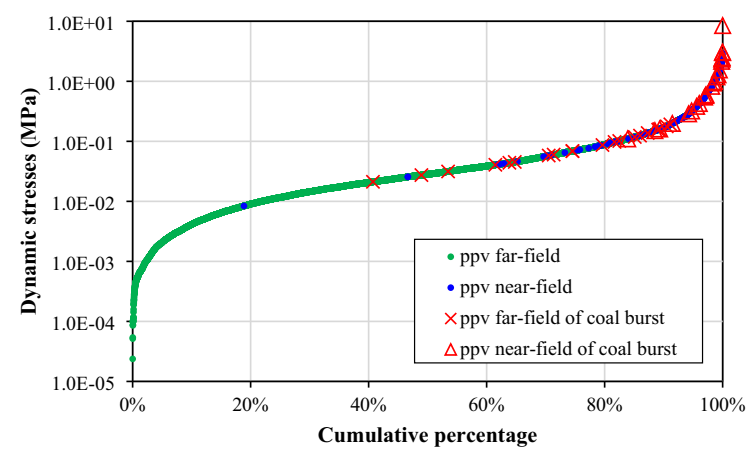

Fig. 13 Ground motions and equivalent dynamic stresses that seismic events impart to LW250105 roadway coal bursts produced are $2.95 \mathrm{MPa}$ and $8.48 \mathrm{MPa}$, respectively, which are $0.2-0.6$ time of the coal UCS. The results demonstrate that most ground motions cause negligible dynamic impacts on roadways, and coal bursts in this condition may only occur when the coal and rock mass are already critically stressed. But if ground motions are significantly large, it is still possible to initiate dynamic failure in mine openings by a considerable dynamic stress transmission.

\section{Correlation between historical ground motions and burst damage}

\subsection{Number of high ground motions}

It has been suggested in the Introduction that ground motions have a cumulative impact on increasing support vulnerability and burst damage risks around excavations. As indicated in Sect. 4, $p p v_{\text {near-field }}$ presented a much higher ground motion intensity than $p p v_{\text {far-field }}$ in the studied case. However, the current ground motion analysis for burst hazard forecasting and control commonly excludes near-field sources (Cai and Kaiser 2018). The ignorance of near-field ground motions can underestimate the cumulative damage induced by seismic events, which may cause unexpected roadway instability to coal burst. Therefore, to comprehensively assess coal burst risks by using both far-field and near-field ground motions, an index called the number of high ground motions $(N H G M)$ was proposed to investigate the relationship between the frequencies of intensive ground motions recorded in the past and actual burst damage observed in roadways.

NHGM records the cumulative number of historical ground motions on roadways that are larger than a

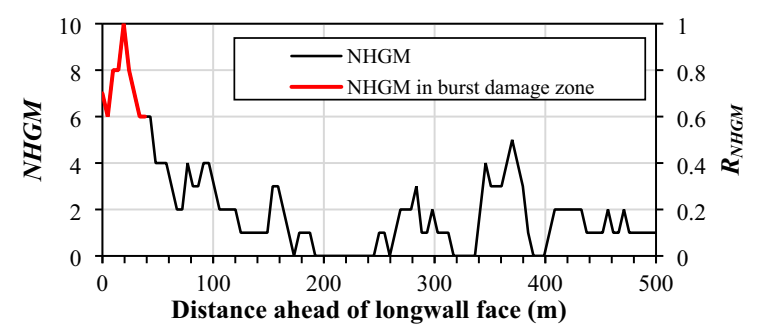

Fig. $14 N H G M$ a distribution on the tailgate before coal burst occurred on 6 September 2014. Red line and marks the burst damage position 


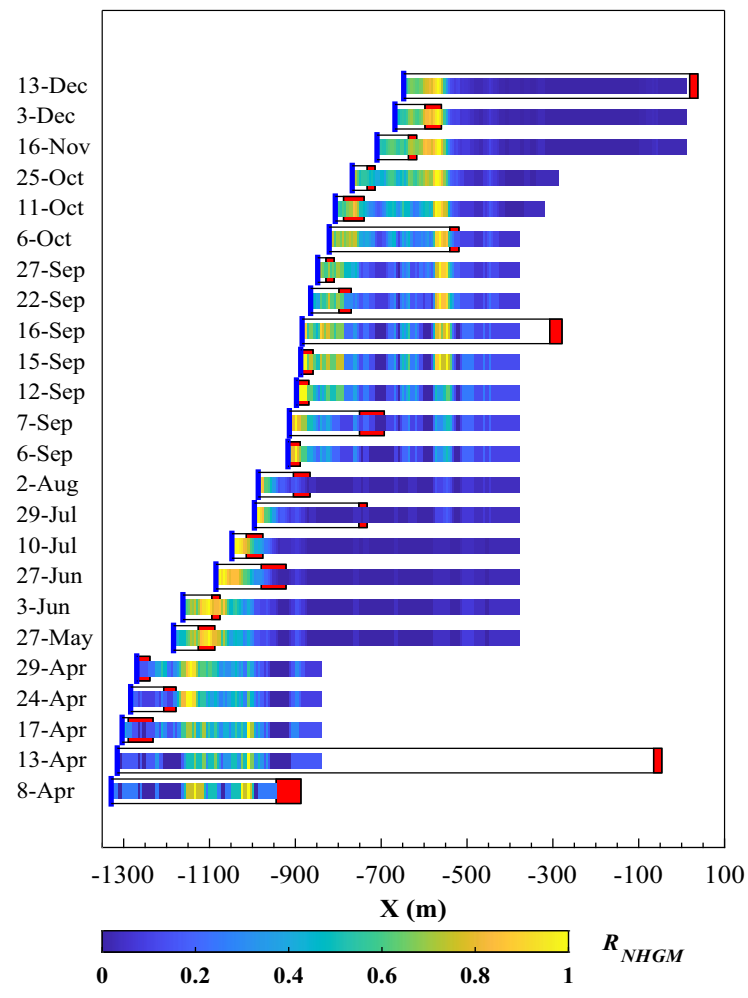

Fig. $15 R_{N H G M}$ distributions in LW250105 tailgate before coal bursts occurrence

given threshold. The roadway length is discretised into several small sections (in $10 \mathrm{~m}$ interval), and within each section $i, N H G M$ is calculated as:

$\operatorname{NHGM}_{(i)}=\sum_{j=1}^{q} y(j), \ldots y(j)= \begin{cases}1 & \left(p p v_{j} \geq p p v_{k}\right) \\ 0 & \left(p p v_{j}<p p v_{k}\right)\end{cases}$
In the above equations, $p p v_{j}$ is the ground motion resulting from the $j^{\text {th }}$ seismic event, $q$ is the last seismic event recorded. $p p v_{k}$ is the threshold for NHGM to filter out low-intensity ground motions. As seismicity and ground motions are highly site-dependent, $p p v_{k}$ can vary among different underground mines. For the study site, the $p p v_{\mathrm{k}}$ is set as $0.01 \mathrm{~m} / \mathrm{s}$, which is about the $85^{\text {th }}$ percentile of all ground motions. With the longwall face retreating, more sections in the roadway ahead of the working face will move into the seismically active zone and their NHGM start to be registered and increase. This study adopts daily $N H G M$ assessment, and it only considers the roadway sections ahead of the working face that has undergone ground motions Thus, the number of sections in NHGM results may varies between different dates.

As $N H G M$ is a parameter derived from seismic events, its value is related to the active degree of seismic events. The factors controlling the active degree of seismic events includes stress conditions, geological structures, mining rate, seismic monitoring quality at the time, pre-destressing operations, etc. As these factors vary along with the mining process, a significant difference in the active degree of seismic events between different periods may present, which usually results in a bias on seismic parameters. Since the mining conditions and the active degree of seismic events are varying over time, identical $N H G M$ over a given period may not indicate the same coal burst risks. To remove bias and assess coal burst risks in general, a normalised $N H G M$ is required. Therefore, the NHGM within each section $i$ was further

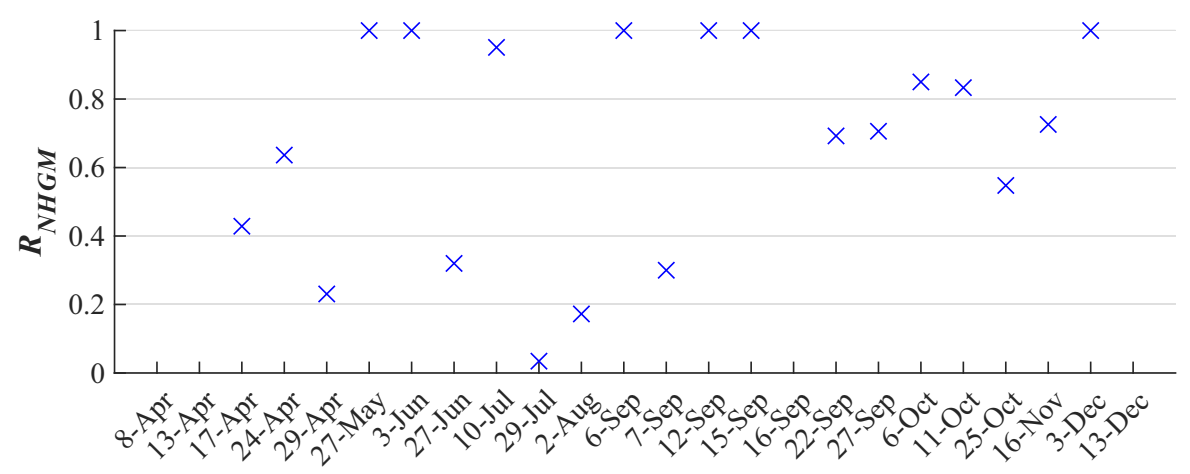

Coal burst date

Fig. $16 R_{N H G M}$ in burst damage zones in LW250105 


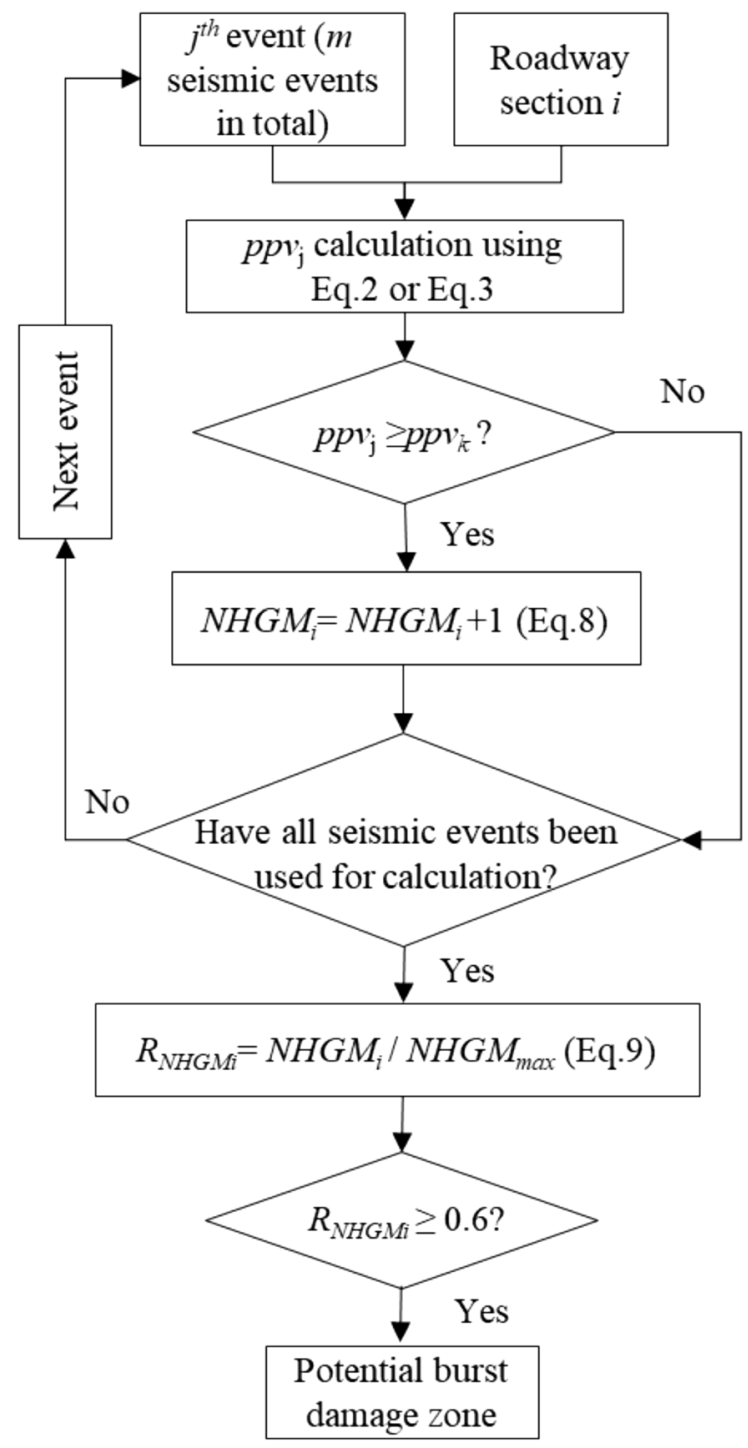

Fig. 17 Flowchart of $R_{N H G M}$ calculation and burst damage potential identification for a roadway section

normalised by $N H G M_{\max }$, which is the maximum $N H G M$ of the daily $N H G M$ result:

$$
R_{N H G M(i)}=N H G M(i) / N H G M_{\max }
$$

\subsection{Back analysis}

Ground motions from all seismic events at LW250105 panel are used to calculate $N H G M$ at the tailgate. 24 coal burst incidents with detailed reports on actual burst damage zones in the tailgate are used. The NHGM results for each incident is calculated using the seismic data from April 2014 to the day before the onset of the coal burst. Figure 14 is an example of NHGM distribution in the tailgate ahead of the longwall face (outby), before the coal burst occurrence on 6 September 2014. NHGM is calculated as $6 \sim 10$. The NHGM distribution shows high values within $50 \mathrm{~m}$ away from the longwall face, and a downward trend is presented as further increasing the distance to the face. Figure 14 shows that the tailgate within $50 \mathrm{~m}$ away from the longwall face has a relatively higher instability than other zones due to the intensive ground motions that section experienced. The burst damage zone was located in the highest $N H G M$ zone where $R_{N H G M}$ is 1 . It indicates that coal burst damage has a strong correlation with high $R_{N H G M}$ values in this example.

Figure 15 shows the $R_{N H G M}$ results and the actual damage zones in LW250105 tailgate induced by 24 coal bursts. For better visualisation, the $R_{N H G M}$ distributions are presented as colour bars. The bottom of the colour bar represents the latest longwall face position before a coal burst occurrence. Only 20 coal bursts have the $R_{N H G M}$ results for this analysis. No $R_{N H G M}$ can be calculated for the coal bursts on 8 April, 13 April, 16 September and 13 December, as the damage zone caused by them were outside the seismic active zone. The $R_{N H G M}$ results of damage zones in Fig. 16 shows that $65 \%(13 / 20)$ of the burst damage occurred in the zone with the maximum $R_{N H G M}$ larger than 0.6. Also, about $45 \%(9 / 20)$ of the burst damage zones have the maximum $R_{N H G M}$ larger than 0.8 . It indicates that the roadway zone with higher $R_{N H G M}$ values has higher burst damage risk.

The results in Fig. 16 indicates that roadways with $R_{N H G M}$ larger than 0.6 can be in high burst risk due to a deep failure of surroundings and high vulnerability of support systems. Therefore, $R_{N H G M}$ of 0.6 is suggested as the threshold to identify potential burst damage zones. The procedure of calculating $R_{N H G M}$ and identifying potential burst damage in a roadway section $(i)$ is shown as a flow chart in Fig. 17. However, there are some burst incidents before May 2014 with no $R_{N H G M}$ result or with values lower than 0.6. One of the main reasons could be the high magnitude of completeness during the period. The magnitude of completeness $\left(m_{c}\right)$ is used to describe the integrity of seismic data, which is the minimum magnitude at which seismic events can be reliably recorded. Based on the Gutenberg-Richter 
Fig. 18 a An example of frequency-magnitude relationship and magnitude of completeness.

b Magnitude of completeness before the occurrence of coal bursts

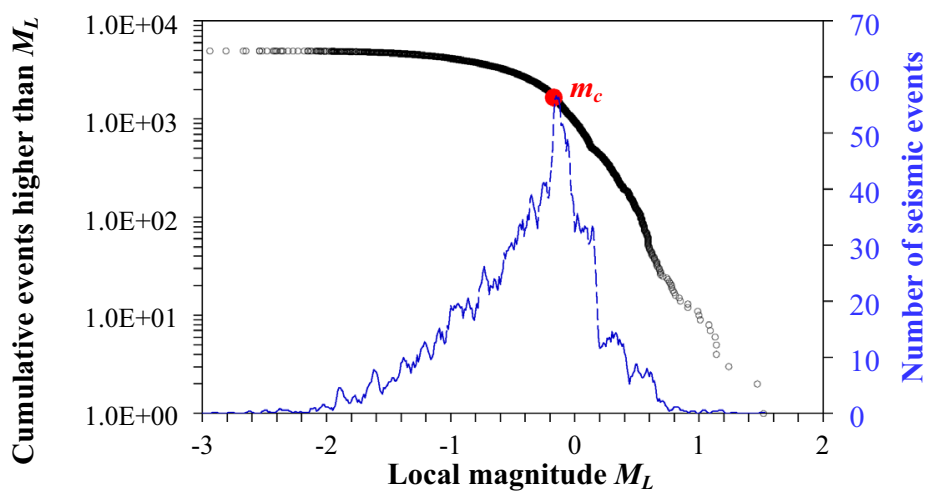

(a)

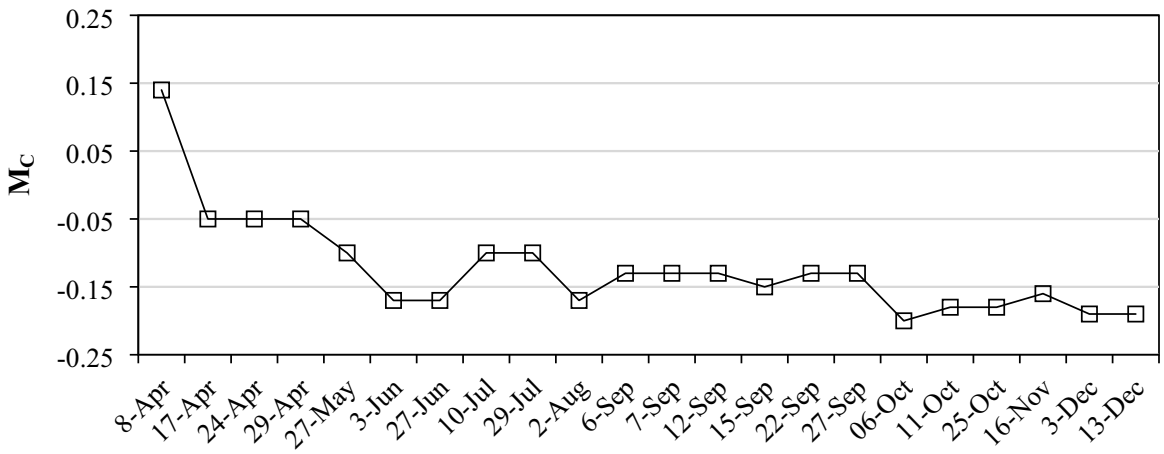

(b)

Coal burst date
Frequency-Magnitude relationship, the frequency and magnitude of seismic events follow a power-law distribution. Therefore, $m_{c}$ as the peak value (as an example shown in Fig. 18a) indicates the minimum magnitude of events that can be fully detected using the current monitoring system. In order to assess the integrity of the seismic data, the energy of seismic events recorded before each studied coal burst event is first transferred to local magnitude by Ryder and Jager (2002):

$\log E_{S}=1.5 M_{L}-1.2$

where the unit of seismic energy $E_{S}$ is MJ. Then the $m_{c}$ for individual burst cases can be derived, which are plotted in Fig. 18b. This figure shows that a relatively high $m_{c}$ with values up to 0.15 was presented in April 2014. It indicates that the seismic events with magnitude lower than 0.15 , equivalent to about $105 \mathrm{~kJ}$, were only partially detected during the period. According to the ground motions results in Sect. 4, seismic events with such intensities can generate $p p v_{\text {far-field }}$ of up to $0.014 \mathrm{~m} / \mathrm{s}$ and $p p v_{\text {near-field }}$ of
$0.085 \mathrm{~m} / \mathrm{s}$. Therefore, the low detection probability of these events can lead to a bias in $R_{N H G M}$ results. From June 2014, $m_{c}$ decreased and fluctuated at around -0.15 , showing the better integrity of seismic data, which contributes to more reliable $R_{N H G M}$ results with less bias.

\section{Conclusions}

In this paper, a comprehensive ground motion analysis was implemented to explore dynamic impacts from seismic events on roadways and their relations with coal burst damage. The ground motions that roadways have undergone in both near-field and far-field zones have been quantified. The ground motion-induced cumulative damage in roadway surroundings have also been illustrated by the proposed index (NHGM). The results indicated that $p p v_{\text {near-field }}$ has an overall much higher intensity than $p p v_{\text {far-field. }}$ Compared with the rockbursts recorded in literatures, both $p p v_{\text {far-field }}$ and $p p v_{\text {near-field }}$ of the coal bursts had much lower 
intensities. However, for seismic events at the same energy level, ground motion intensities in coal mines can be nearly 100 times higher than that in hard rock mines. In most cases, ground motions only generate negligible dynamic impacts on roadways, and coal bursts may be triggered when the coal and rock mass is already critically stressed. But for some significant ground motions, they may contribute to producing considerable stress increment and initiating dynamic failure. The NHGM results demonstrated that coal bursts had a higher possibility to occur in higher $R_{N H G M}$ zones, i.e. the zone that has experienced more cumulative damage from past intensive ground motions. A low detection probability of the seismic monitoring system may lead to the failure of applying NHGM to assess coal burst risks. This study can contribute to providing a powerful tool for coal burst forecasting and roadway instability assessment in ground motion terms.

Acknowledgements The first author acknowledges the financial support of the China Scholarship Council-University of NSW, Sydney Project (No. 201706420062).

Funding Open Access funding enabled and organized by CAUL and its Member Institutions.

\section{Declarations}

Conflict of interest All authors declare that there is no conflict of interest for this paper.

Open Access This article is licensed under a Creative Commons Attribution 4.0 International License, which permits use, sharing, adaptation, distribution and reproduction in any medium or format, as long as you give appropriate credit to the original author(s) and the source, provide a link to the Creative Commons licence, and indicate if changes were made. The images or other third party material in this article are included in the article's Creative Commons licence, unless indicated otherwise in a credit line to the material. If material is not included in the article's Creative Commons licence and your intended use is not permitted by statutory regulation or exceeds the permitted use, you will need to obtain permission directly from the copyright holder. To view a copy of this licence, visit http://creativecommons.org/licenses/by/4.0/.

\section{References}

Bai J, Shen W, Guo G, Wang X, Yu Y (2015) Roof deformation, failure characteristics, and preventive techniques of gobside entry driving heading adjacent to the advancing working face. Rock Mech Rock Eng 48:2447-2458. https://doi.org/10.1007/s00603-015-0713-2
Boatwright J (1988) The seismic radiation from composite models of faulting. Bull Seismol Soc Am 78:489-508

Bräuner G (2017) Rockbursts in coal mines and their prevention. A.A.Balkema, Rotterdam

Cai M, Kaiser PK (2018) Rockburst support reference book, vol I. Rockburst phenomenon and support characteristics. MIRARCO, Canada

Cai W, Bai X, Si G, Cao W, Gong S, Dou L (2020) A monitoring investigation into rock burst mechanism based on the coupled theory of static and dynamic stresses. Rock Mech Rock Eng 53:5451-5471. https://doi.org/10.1007/s00603020-02237-6

Cai W, Dou L, Si G, Cao A, Gong S, Wang G, Yuan S (2019) A new seismic-based strain energy methodology for coal burst forecasting in underground coal mines. Int $\mathrm{J}$ Rock Mech Min Sci 123:104086. https://doi.org/10.1016/j. ijrmms.2019.104086

Cao W, Shi J, Si G, Durucan S, Korre A (2018) Numerical modelling of microseismicity associated with longwall coal mining. Int J Coal Geol 193:30-45. https://doi.org/10. 1016/j.coal.2018.04.010

Cichowicz A (2001) The meaningful use of peak particle velocity at excavation surface for the optimisation of the rockburst support criteria for tunnels and stopes. Mine Health and Safety Council, Johannesburg

Cook NGW (1965) A note on rockbursts considered as a problem of stability. J S Afr I Min Metall 65:437-446

Dou L, Cao A, Gong S, Cai W (2016) Mining geophysics and vibration. China University of Mining and Technology Press, Xuzhou

Dubinski J, Mutke G (1997) Characteristics of near-field peak velocity in the Upper Silesian Coal Mines. In: Proceedings of 4th international symposium on rockburst and seismicity in mines, Kraków, Poland. Balkema, pp 343-347

Dubiński J, Mutke G (1996) Characteristics of mining tremors within the near-wave field zone. In: Induced seismic events. Birkhäuser Basel, pp 249-261

Gibowicz SJ, Kijko A (1994) An introduction to mining seismology. Polish Academy of Sciences, Warsaw

Glazer S (2018) Mine seismology: seismic warning concept. Springer

Jager A, Ryder J (1999) A handbook on rock engineering practice for tabular hard rock mines. Safety in Mines Research Advisory Committee, Johannesburg

Jia C, Luan H, Chen Z (2014) Supporting technique of gob-side entry driving in asymmetric island coal face in deep and its application. J Electron J Geotech Eng 19:10539-10550

Ju W, Zheng J, Wei D, Sun L, Li W (2019) Study on the causes and control technology about the coal bump in multi-layered mining roadway in steep-thick coal seams. J Min Saf Eng 36:280-289

Kaiser PK (1996) Canadian rockburst support handbook. Geomechanics Research Centre, Canada

Kaiser PK (2006) Rock mechanics considerations for construction of deep tunnels in brittle rock. In: Leung CF, Zhou YX (eds) Rock mechanics in underground construction. World Scientific, Singapore, pp 47-58

Kaiser PK, Cai M (2013a) Critical review of design principles for rock support in burst-prone ground-time to rethink! In: Proceedings of the 7th international symposium on ground 
support in mining and underground construction, Australia. Australian Centre for Geomechanics, pp 3-37

Kaiser PK, Cai M (2013b) Keynote lecture: rockburst damage mechanisms and support design principles. In: Malovichko A, Malovichko D (eds) Proceedings of the 8th international symposium on rockbursts and seismicity in mines. Geophysical Survey of Russian Academy of Sciences, Moscow, pp 349-370

Kaiser PK, Maloney SM (1997) Scaling laws for the design of rock support. Pure Appl Geophys 150:415-434

Kaiser PK, Vasak P, Suorineni F, Thibodeau D (2005) New dimensions in seismic data interpretation with 3-D virtual reality visualization for burst-prone mines. In: Proceedings of 6 th international symposium on rockburst and seismicity in mines, Australia, 2005. Australian Centre for Geomechanics, pp 33-45

Li Z, Li J, Li X (2019) Seismic interaction between a semicylindrical hill and a nearby underground cavity under plane SH waves. Geomech Geophys Geo-Energy GeoResour 5:405-423. https://doi.org/10.1007/s40948-01900120-5

Martin C, Kaiser PK, McCreath D (1999) Hoek-Brown parameters for predicting the depth of brittle failure around tunnels. Can Geotech J 36:136-151. https://doi.org/10. $1139 / \mathrm{t} 98-072$

McGarr A (1984) Scaling of ground motion parameters, state of stress, and focal depth. J Geophys Res-Sol Ea 89:6969-6979. https://doi.org/10.1029/JB089iB08p06969

McGarr A (1991) Observations constraining near-source ground motion estimated from locally recorded seismograms. J Geophys Res Solid Earth 96:16495-16508. https://doi.org/10.1029/91jb01379

McGarr A, Green R, Spottiswoode S (1981) Strong ground motion of mine tremors: some implications for near-source ground motion parameters. Bull Seismol Soc Am 71:295-319

Mendecki AJ (1996) Seismic monitoring in mines. Chapman \& Hall, London

Mendecki AJ (2016) Mine seismology reference book: seismic hazard. Institute of Mine Seismology

Milev A, Spottiswoode S, Noble B, Linzer L, Van Zyl M, Daehnke A, Acheampong E (2002) Meaningful use of peak particle velocities at excavation surfaces for the optimisation of the rockburst criteria for tunnels and stopes (GAP709). Safety in Mines Research Advisory Committee

Milev S (2005) Strong ground motion and site response in deep South African mines. J S Afr I Min Metall 105:515-524

Mutke G (2002) Ground motion associated with coal mine tremors close to the underground openings. In: Seismogenic process monitoring. AA Balkema, pp 91-102

Ortlepp W (2005) RaSiM comes of age-a review of the contribution to the understanding and control of mine rockbursts. In: Proceedings of the 6th international symposium on rockburst and seismicity in mines, Australia, 2005. Australian Centre for Geomechanics, Western Australia, pp 3-20
Owen ML (2005) Calibrating a semi-quantitative seismic risk model using rockburst case studies from underground metalliferous mines. In: Proceedings of 6th international symposium on rockburst and seismicity in mines, Australia, 2005. Australian Centre for Geomechanics, pp 191-204

Perret WR (1972) Seismic-source energies of underground nuclear explosions. Bull Seismol Soc Am 62:763-774

Ptáček J (2017) Rockburst in Ostrava-Karvina coalfield. Procedia Eng 191:1144-1151

Qian D, Sasaoka T, Shimada H, Wahyudi S, Tsedendorj A, Wang C, Matsui K (2014) Analysis of coal pillar width and stability control of gob-side entry driving in deep island coal face. In: ISRM international symposium-8th Asian rock mechanics symposium, 2014. OnePetro

Qiu J, Liu K, Li X, Li D, Wang F (2021) Influence of blasting disturbance on dynamic response and safety of deep tunnels. Geomech Geophys Geo-Energ Geo-Resour 8:5. https://doi.org/10.1007/s40948-021-00308-8

Roberts MKC, Brummer RK (1988) Support requirements in rockburst conditions. J S Afr I Min Metall 88:97-104

Ryder JA, Jager AJ (2002) A textbook on rock mechanics for tabular hard rock mines. The Safety in Mines Research Advisory Committee, Johannesburg

Shearer PM (2009) Introduction to seismology. Cambridge University Press, New York

Si G, Cai W, Wang S, Li X (2020) Prediction of relatively highenergy seismic events using spatial-temporal parametrisation of mining-induced seismicity. Rock Mech Rock Eng 53:5111-5132. https://doi.org/10.1007/s00603-02002210-3

Stec K (2007) Characteristics of seismic activity of the Upper Silesian Coal Basin in Poland. Geophys J Int 168:757-768. https://doi.org/10.1111/j.1365-246X.2006.03227.x

Wu R, He Q, Oh J, Li Z, Zhang C (2018) A new gob-side entry layout method for two-entry longwall systems. Energies 11:2084

Xie H, Zhu J, Zhou T, Zhang K, Zhou C (2020) Conceptualization and preliminary study of engineering disturbed rock dynamics. Geomech Geophys Geo-Energ Geo-Resour 6:34. https://doi.org/10.1007/s40948-020-00157-x

Zhang C, Canbulat I, Hebblewhite B, Ward CR (2017) Assessing coal burst phenomena in mining and insights into directions for future research. Int $\mathrm{J}$ Coal Geol 179:28-44. https://doi.org/10.1016/j.coal.2017.05.011

Zhong S, Wang C, Guo M, Zhao N (2012) Experimental study on surrounding rock deformation characteristics of gateway driving along next goaf with different thickness limestone roof. In: Sung W, Kao J, Chen R (eds) Frontiers of energy and environmental engineering. CRC Press, Boca Raton, p 316

Publisher's Note Springer Nature remains neutral with regard to jurisdictional claims in published maps and institutional affiliations. 